\title{
Association between intelligence quotient and the 5HTTLPR polymorphism of human serotonin transporter coding gene
}

Nina V. Volf1,3, Nadezhda A. Sinyakova², Ludmila P. Osipova² ${ }^{2}$ Alexander V. Kulikov²,3 and Ludmila V. Belousova ${ }^{1 *}$

${ }^{*}$ Correspondence: Iv-belousova@physiol.ru

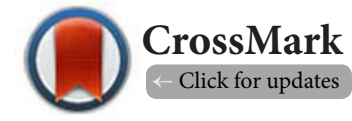

'Institute of Physiology and Fundamental Medicine of Siberian Branch of Russian Academy of Medical Sciences, 630117. Novosibirsk, Russia.

${ }^{2}$ Institute of Cytology and Genetics of Siberian Branch of Russian Academy of Sciences, 630090, Novosibirsk, Russia.

${ }^{3}$ Novosibirsk State Research University, 630090, Novosibirsk, Russia.

\begin{abstract}
Association between common intelligence quotient (IQ) and S and L alleles of functional 5HTTLPR polymorphism causing respectively low and high expression of human serotonin transporter coding gene was studied in young (19-35 years, 50 men and 76 women) and older (>55 years, 39 men and 43 women) Caucasian subjects. They were students, scientists, technicians and administrative staff of Novosibirsk State Universities and State Research Institutes of Russian Academy of Sciences. Significant effects of genotype and age, but not gender on IQ were revealed. Higher IQ scores were observed in the $\mathrm{S} / \mathrm{S}$ genotype carriers compared with the $\mathrm{L} / \mathrm{S}(\mathrm{p}<0.002)$ or $\mathrm{L} / \mathrm{L}(\mathrm{p}<0.003)$ genotype carriers. No effect of the genotype $\mathrm{x}$ gender or genotype $\mathrm{x}$ age interaction was found. Based on this result, we hypothesized an increased frequency of the $\mathrm{S}$ allele in highly educated university group compared with control population. To test this hypothesis the distribution of the alleles and genotypes in the above mentioned academic sample and control population of Caucasian subjects from Dovolnoe village, Novosibirsk region $(\mathrm{n}=83)$ was compared. The frequencies of the $\mathrm{S}$ allele $(43.5 \%)$ and the $\mathrm{S} / \mathrm{S}$ genotype $(20.5 \%)$ in the academic sample were significantly higher than in the controls $(28.2 \%, \mathrm{p}=0.023$ for the $\mathrm{S}$ allele and $10.1 \%, \mathrm{p}=0.011$ for the $\mathrm{S} / \mathrm{S}$ genotype). The results indicate a significant association between IQ scores and the 5HTTLPR polymorphism, the involvement of serotonergic neuromodulation in cognitive functioning and provide further support for the classification of the $\mathrm{S}$ allele and the $\mathrm{S} / \mathrm{S}$ genotype as associated with cognition.
\end{abstract}

Keywords: Human serotonin transporter, 5HTTLPR polymorphism, common IQ, gender, age, level of education

\section{Introduction}

Intelligence is one of the most often investigated psychological construct due to its substantial role for academic achievement and important life outcomes. The heritability of IQ is substantial [11]. Despite this, there is still almost no replicated evidence concerning the individual genes, which have variants that contribute to intelligence differences.

The serotonin transporter mediates the magnitude and duration of serotonin signaling via the neurotransmitter clearance from synaptic cleft $[8,35]$. 5HTTLPR functional polymorphism in the promoter region regulates the transcription of human serotonin transporter gene (SLC6A4). Initially, two polymorphic variants, a long (L) and a short (S) were described [35]. More recently two single nucleotide (the LA and the LG, rs25531) variants of the L allele were described [54]. The LG and the S alleles similarly attenuate the transcriptional activity of SLC6A4 gene; thus, only the LA variant causes high expression of the gene $[26,27]$.

Although the majority of researches have focused on the role of 5-HTTLPR polymorphism in depression, anxiety, and personality traits, a growing literature implicates this polymorphism in the development and integrity of neural systems which 
subserve complex processing [23] and in mediating individual differences in cognitive characteristics [25]. It was reported that serotonin transporter genotype is associated with storage capacity of working memory [2], immediate memory, attention [48], performance in Wisconsin Card Sorting test [9]. Recently, the association between 5-HTTLPR polymorphism and originality of divergent thinking was revealed: $\mathrm{S} / \mathrm{S}$ genotype demonstrated higher figural creativity scores in comparison with the carries of $\mathrm{L} / \mathrm{L}[\mathbf{5 3}]$.

The relationship of divergent thinking with intelligence has

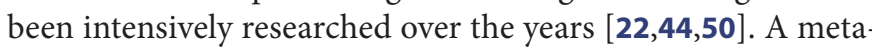
analysis of 21 studies revealed the average correlation between DT and IQ to be 0.17 [33]. It was concluded that intelligence and divergent thinking are different but related constructs [12].

Since 5-HTTLPR polymorphism is associated with divergent thinking, it may also contribute to IQ. We hypothesized that subjects with S/S genotype would have higher IQ scores in comparison with $\mathrm{L} / \mathrm{L}$ carriers, and $\mathrm{S} / \mathrm{S}$ genotype to be more represented among academic population, selected according to the intellectual characteristics, than in non-selected rural community with lower level of education.

However, the relationship between IQ and 5-HTTLPR can be moderated by several factors such as gender or age. Gender difference has been demonstrated to moderate the association between the 5-HTTLPR polymorphism and various phenotypes $[13,38,42,51]$. Serotonin plays an important role in neural development [18] and plasticity [17]. Lesch and Gutknecht [36] proposed that this mechanism contributes for impaired synaptic plasticity in adulthood, and sets the base for later brain dysfunction. Thus, 5-HTTLPR variation may be significant in ageing processes [32].

The present research was focused on the association between 5-HTTLPR polymorphism and IQ. We also intended to study the effect of gender and age on the association between this polymorphism and IQ. We also supposed that frequency of $S$ allele would be higher in highly educated academy sample than in rural community with lower level of education.

\section{Materials and methods}

Two samples of adult unrelated Caucasian subjects were studied. The academic sample included graduate and postgraduate students, scientists, technicians and administrative staff $(n=208)$ of Novosibirsk State Universities and Novosibirsk State Research Institutes of Russian Academy of Sciences which participated in the IQ and 5HTTLPR association study. Most participants in the university sample underwent a rigorous selection for intellectual work. All non-students were employed full time. The participants were grouped by age as young (19-35 years, 50 men and 76 women) and older adults ( $>55$ years, 39 men and 43 women). The sample of 83 age and sex matched adult Caucasian volunteers from Dovolnoe village, Novosibirsk region with previously genotyped 5-HTTLPR was chosen as the control to the academic sample. The control sample included healthy volunteers of different occupation (school teachers, students and lecturers of Dovolnoe's State Agricultural College, farmers, et al.,) which were undergoing preventive medical examination. In Dovolnoe sample IQ was not determined. Their data were used to compare genotype and allele frequencies with above mentioned academic populations. All participants of both samples gave written informed consent and were interviewed for their age, education level and nationality. Exclusion criteria were current and lifetime organic brain syndromes and major medical illnesses. The study was approved by the local Institutional Ethics Committee and conformed to the principles of the Declaration of Helsinki.

Sex, age and years of education (education score) and 5HTTLPR genotypes were registered in all participants in both samples. The years of education were evaluated as the sum of years spent in school (usually 10), university (usually 5) or post-graduate training (usually 3 ).

Common IQ was assessed only in subjects of the academic sample. Validated Russian version of Eysenk test was used [15] because of its lower time consumption in comparison with other validated for Russian population Structure of Intelligence Test [1]. The duration of the study was very important factor for engagement of full time employed participants, especially for full time employed aged subjects.

DNA was extracted from buccal cells to avoid a selective exclusion of subjects with blood and infection phobias. The cells were digested overnight at $50^{\circ} \mathrm{C}$ with protease $\mathrm{K}$ (Helicon, Moscow, Russia) and then saturated $\mathrm{NaCl}$ solution was added to precipitate proteins. DNA was precipitated with 2 volumes of ethanol, washed with $70 \%$ ethanol, dried and dissolved in sterile water and stored at $-20^{\circ} \mathrm{C}$ until use [41]. The $\mathrm{S}$ and $\mathrm{L}$ alleles were detected in the DNA samples using PCR and 5'-ggcgttgccgctctgaattgc-3' and 5'-gagggactgagctggacaacccac-3' primers followed by the PCR product separation on $2 \%$ agarose gel [35]. The size of amplicon for L allele was $529 \mathrm{bp}$, while that for $\mathrm{S}$ allele was $489 \mathrm{bp}$.

For diagnosis of LA and LG alleles the products of amplification were digested for three hours with MspI endonuclease (Sybenzyme, Novosibirsk, Russia). The products of digestion were separated on $3 \%$ agarose gel. The sizes of products of digestion of LA allele were 340, 127 and $62 \mathrm{bp}$, while those for LG allele were 174, 166, 127 and 62 bp [34].

The frequency of the LG allele was low. Therefore, in the present study we could not test the effect of the LG allele on common IQ. Taking into account their functional equivalence, the LG and the S alleles were grouped together as S (lower expressing) allele and the $\mathrm{LA}$ allele was designated as $\mathrm{L}$ as it was done in other studies [48].

IQ data were analyzed with three-way ANOVA in order to examine effects of the factors: Genotype, Gender (men, women), Age (young, older) and their interactions. The post-hoc Scheffer comparison was used where appropriate. The genotype frequencies were tested for Hardy-Weinberg equilibrium using $\chi 2$-test. The alleles and genotypes frequencies in the university and control samples were compared using $\chi 2$-test. Education level 
and age were analyzed with the nonparametric Kruskal-Wallis and Mann-Whitney tests.

\section{Results}

Number of men and women, genotypes, age and years of education for each of two studied samples were presented in Table 1. For each sample age and years of education did not differ between the genders or the genotype subgroups. There was also equal proportion of men and women in the same genotype group. The 5HTTLPR genotypes were distributed according to Hardy-Weinberg equilibrium in each of two studied samples (Table 1). Education level of the subject in the university sample $(14.7 \pm 0.14)$ was significantly higher compared with that in the control sample from Dovolnoe village $(11.1 \pm 0.35, Z=14.45$, $\mathrm{p}<0.0001)$. Moreover, the years of education score in the genotypic subgroups of the university sample was significantly higher than in the same genotypic subgroups of the control sample: $\mathrm{Z}=5.11, \mathrm{p}<0.001$ for $\mathrm{L} / \mathrm{L} ; \mathrm{Z}=4.71, \mathrm{p}<0.001$ for $\mathrm{S} / \mathrm{L}$; and $\mathrm{Z}=3.34$, $\mathrm{p}<0.001$ for $\mathrm{S} / \mathrm{S}$ genotypes.

Significant effects of the main factors such as Genotype and Age, but not Gender on IQ were shown (Table 2). Analysis of respective means indicates that IQ scores were higher in young in comparison with older participants (Table 2). The S/S carriers demonstrated higher IQ scores in comparison with the $\mathrm{L} / \mathrm{L}$ and $\mathrm{S} / \mathrm{L}$ carriers (Table 2). No significant interactions between the factors were found (Table 2).

The frequency of $S$ allele in the total sample including both the university and the control (Dovolnoe) samples was 0.39 , while in the university and the control samples the frequencies of $S$ allele were 0.43 and 0.28 , respectively. The frequency of $S / S$ genotype (20.2\%) in the university sample was higher compared with frequency in the control population $(8.4 \%, \mathrm{p}=0.016$, Figure 1$)$.

Table 1. Gender (numbers of men and women), age and years of education (mean \pm SEM) for each genotype of 5 HTTLPR polymorphism within two investigated samples.

\begin{tabular}{|c|c|c|c|c|}
\hline & $\mathrm{L} / \mathrm{L}$ & $\mathrm{L} / \mathrm{S}$ & $S / S$ & Statistics \\
\hline \multicolumn{5}{|c|}{$\begin{array}{l}\text { University sample of subjects included in 5HTTLPR genotype and } \\
\text { IQ association study }\end{array}$} \\
\hline $\operatorname{Men}(\mathrm{n})$ & 26 & 45 & 18 & $\chi^{2}=0.06, p=0.49^{a}$ \\
\hline Age & $47.1 \pm$ & $40.5 \pm$ & $35.0 \pm 4.9$ & \\
\hline Years of education & $15.3 \pm 0.4$ & $14.9 \pm 0.3$ & $14.8 \pm 0.5$ & $\chi^{2}=0.6, p=0.37$ \\
\hline Women (n) & 39 & 56 & 24 & $\chi^{2}=0.1, p=0.48^{a}$ \\
\hline Age & $39.6 \pm 3$ & $33.2 \pm 2.8$ & $39.8 \pm 4.3$ & $\chi^{2}=1.9, p=0.195$ \\
\hline Years of education & $14.6 \pm 0.3$ & $14.3 \pm 0.3$ & $14.8 \pm 0.4$ & $\chi^{2}=0.5, p=0.39$ \\
\hline
\end{tabular}

Control sample of villagers from dovolnoe village of novosibirsk region

\begin{tabular}{lllll}
\hline Men (n) & 19 & 17 & 3 & $\chi^{2}=0.09, \mathrm{p}=0.43^{\mathrm{a}}$ \\
Age & $43.4 \pm 4.5$ & $52.8 \pm 4.74$ & $59.7 \pm 11.3$ & $\chi^{2}=4.4, \mathrm{p}=0.055$ \\
Years of education & $11.8 \pm 0.8$ & $10.3 \pm 0.7$ & $10.0 \pm 1.7$ & $\chi^{2}=3.7, \mathrm{p}=0.08$ \\
Women (n) & 25 & 15 & 4 & $\chi^{2}=0.6, \mathrm{p}=0.37^{\mathrm{a}}$ \\
Age & $44.2 \pm 34.9$ & $53.9 \pm 5.1$ & $52.2 \pm 9.8$ & $\chi^{2}=1.0, \mathrm{p}=0.30$ \\
Years of education & $10.9 \pm 0.6$ & $12.1 \pm 0.9$ & $11.0 \pm 1.5$ & $\chi^{2}=4.4, \mathrm{p}=0.055$ \\
\hline
\end{tabular}

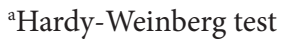

Table 2. ANOVA main effects including descriptive statistics (means \pm SEM).

\begin{tabular}{lll}
\hline & $\mathbf{N}$ & $\mathbf{I Q}$ \\
\hline Genotype & & $\mathbf{F}_{2,196}=\mathbf{3 . 4 6}, \mathbf{p}=\mathbf{0 . 0 3 3}$ \\
\hline L/L & 65 & $107.1 \pm 1.7, \mathrm{p}=0.018$ vs $/ \mathrm{S}$ \\
L/S & 101 & $107.4 \pm 1.4, \mathrm{p}=0.016$ vs $/ \mathrm{S}$ \\
S/S & 42 & $113.7 \pm 2.2$ \\
\hline Gender & & $\mathbf{F}_{1,196}<\mathbf{1}$ \\
\hline Men & 89 & $109.6 \pm 1.6$ \\
Women & 119 & $109.2 \pm 1.3$ \\
\hline Age & & $\mathbf{F}_{1,19}=\mathbf{4 0 . 6 7}, \mathbf{p}<\mathbf{0 . 0 0 0 1}$ \\
\hline Young & 126 & $115.9 \pm 1.3$ \\
Old & 82 & $102.8 \pm 1.6$ \\
\hline
\end{tabular}

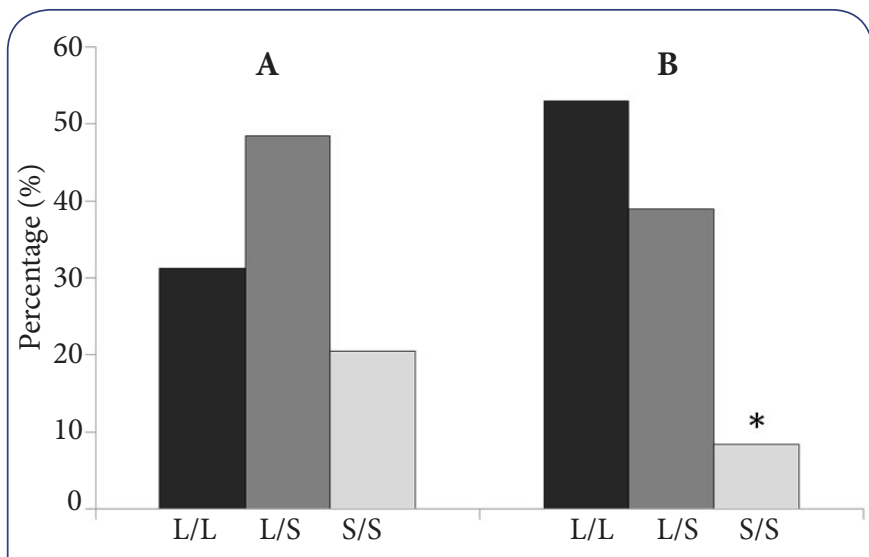

Figure 1. Distribution of $\mathrm{L} / \mathrm{L}, \mathrm{L} / \mathrm{S}$ and $\mathrm{S} / \mathrm{S}$ genotypes in the university (A) and control (B) samples. The university sample included graduate and postgraduate students, scientists, technicians and administrative staff of Novosibirsk State Universities and Novosibirsk State Research Institutes of Russian Academy of Sciences $(n=208)$. The control sample included villagers from Dovolnoe village of Novosibirsk region $(\mathrm{n}=83) .{ }^{*} \mathrm{p}=0.016$ vs control group.

\section{Discussion}

The main result of this study indicates a significant association between common IQ scores and the 5HTTLPR polymorphism in SLC6A4 gene. Higher IQ scores were observed in the S/S genotype carriers in comparison with the S/L or the L/L genotype carriers.

Significant effect of Genotype x Gender or Genotype x Age interaction was not found. Therefore, gender and age did not moderate the observed main effect of association between S/S genotype and high IQ score.

In the present study a lower IQ score in older versus young participants was shown. This result was not unexpected since Russian version IQ test was not age adjusted. It is known that older peoples usually show a delayed reaction time and, therefore, complete fewer tasks in the limited time of IQ testing. 
This association between S/S genotype and high IQ score was confirmed by higher frequencies of the $S$ allele and the S/S genotype among the university sample selected according to the high academic achievement and having higher education level (evaluated by years of education) compared with the non-selected population from village Dovolnoe. This result agrees with the finding that IQ correlates 0.5 to 0.7 with academic achievement [31].

We have recently described the association between $\mathrm{S} / \mathrm{S}$ genotype and higher creativity [53]. Present results add new evidence concerning the importance of serotonergic neuromodulation in IQ. In the brain the 5-HT afferents are particularly abundant in the frontal cortex $[\mathbf{3}, \mathbf{2 8}]$. It has been shown that frontal cortex may play an important role in both general intelligence $[20]$ and creativity $[10,29]$. It was also found that while lower creative persons showed little variance between convergent and divergent processing in the activation of their frontal cortices, highly creative individuals displayed more variability in the frontal areas. Therefore, it was hypothesized that highly creative individuals easily switched between different modes of cognitive processing [29]. It is intriguing to speculate that flexibility of S/S genotype may be associated with increased frontal flexibility.

The S allele and S/S genotype decrease SLC6A4 gene expression and rate of 5-HT reuptake and they are usually considered to be associated with an impairment of 5-HT synapse function [35]. Some authors associate the $S$ allele with such negative characteristics as violence $[6,37]$, alcohol $[16,24]$, drug addiction [19] and suicide [21]. In the present and previous [53] studies, we demonstrated association between the 5HTTLPR polymorphism and such positive mental characteristic as IQ and creativity, respectively. It was also reported that while performing a risk decision-making task, the persons with S/S and $\mathrm{L} / \mathrm{S}$ genotypes attended to differences in the probability of winning chosen gambles on a greater extent than those with $\mathrm{L} / \mathrm{L}$ genotype [47]. The S/S genotype carriers outperformed the L/L genotype carriers on a visual planning task, tests for memory and attention [2,46-48]. Carriers of the $S$ allele had a superior performance compared to the $\mathrm{L} / \mathrm{L}$ carriers in Wisconsin Card Sorting Test [9]. A number of studies have also reported that serotonin transporter antagonists improved such cognitive abilities as attention, visual and verbal memory, working memory, and processing speed in animals and human subjects $[\mathbf{3 0}, \mathbf{4 0}, \mathbf{4 3}]$.

So, it may be hypothesized that the association with superior performance in a number of cognitive tasks is a possible evolutionary advantage to conserve the $S$ allele in human population, which may counterbalance its disadvantage of vulnerability to mood disorders. Nevertheless, S/S genotype was described as a 'vulnerability to depression' factor. This hypothesis comes from a disproportionate attention paid to the negative effects of contextual adversity which confirmed the relationship between the 5HTTLPR polymorphism of serotonin transporter gene and environmental adversity, leading to depression [52]. However, S/S form carriers were also found to be more susceptible to environmental events not only for worse but and for better too. A number of reports reveal a beneficial effect of the S/S genotype in low-stress and supportive environments. The $\mathrm{S} / \mathrm{S}$ genotype is associated with elevated depressive symptoms in high-stress environments, yet in low-stress environments the $\mathrm{S} / \mathrm{S}$ genotype is associated with reduced depressive symptom levels relative the L/L genotype $[14,55]$. Attentional biases towards emotionally positive as well as negative images occur in $S$ carriers $[4,5]$. Finally, a recent report showed that strong attentional biases can be trained in $S$ carriers for both positive and negative stimuli [17]. These findings show the plasticity role of the S/S genotype and support the classification of the double short form of the 5-HTTLPR polymorphism as associated with sensitivity to environment rather than predisposition to depression $[\mathbf{7 , 4 9 ]}$.

This study has several limitations that should be noted. 5-HTTLPR polymorphism is associated with sensitivity to environment. It has been showed that such socio-economic attribute as education covaries with serotonergic responsivity [39]. As IQ was assessed only in academic population the different effect of 5-HTTLPR polymorphism on IQ across environments cannot be excluded. Further research evaluating the effects of serotonin-transporter gene polymorphisms on IQ should consider environment as potential moderator. There is great controversy regarding the utility of single variant genetic association studies [45]. So, our findings are best treated as preliminary until cross-validated in additional samples. Although 5-HTTLPR polymorphism has been studied widely we did not find data concerning association between this polymorphism and IQ. The significance of our results lies in the demonstration that 5-HTTLPR polymorphism should be approached as associated with cognitive abilities.

\section{Competing interests}

The authors declare that they have no competing interests.

\section{Authors' contributions}

NVV designed the study, analyzed results and wrote the manuscript, NAS was involved in collection of DNA in academic sample and in diagnosis of alleles of 5-HTTLPR, LPO was involved in collection of DNA in Dovolnoe population and in diagnosis of alleles of 5-HTTLPR, LVB recruited the participants and conducted IQ testing in academic sample, ANK contributed to the analysis on the data and in writing of the manuscript.

\section{Acknowledgement}

The work was supported by the Russian Foundation for Basic Research (grant 13-04-00182) and the Program "Molecular and Cell Biology" of Russian Academy of Sciences (grant 6.7).

\section{Publication history}

Vinay Parikh, Temple University, USA.

Bertram Opitz,University of Surrey, UK.

Received: 13 April 2015 Revised: 25 August 2015

Accepted: 17 September 2015 Published: 26 September 2015

\section{References}

1. Amthauer R, Brocke B, Liepmann D and Beauducel A. Intelligenz-Struktur-Test 2000 R. Hogrefe, Göttingen. 2001.

2. Anderson DE, Bell TA and Awh E. Polymorphisms in the 5-HTTLPR gene mediate storage capacity of visual working memory. J Cogn Neurosci. 
Belousova et al, Journal of Psychiatry and Brain Functions 2015,

http://www.hoajonline.com/journals/pdf/2055-3447-2-8.pdf

doi: $10.7243 / 2055-3447-2-8$

\section{2; 24:1069-76. | Article | PubMed Abstract | PubMed FullText}

3. Bang SJ, Jensen P, Dymecki SM and Commons KG. Projections and interconnections of genetically defined serotonin neurons in mice. Eur $J$ Neurosci. 2012; 35:85-96. | Article | PubMed Abstract | PubMed FullText

4. Beevers CG, Ellis AJ, Wells TT and McGeary JE. Serotonin transporter gene promoter region polymorphism and selective processing of emotional images. Biol Psychol. 2010; 83:260-5. | Article | PubMed Abstract I PubMed FullText

5. Beevers CG, Wells TT, Ellis AJ and McGeary JE. Association of the serotonin transporter gene promoter region (5-HTTLPR) polymorphism with biased attention for emotional stimuli. J Abnorm Psychol. 2009; 118:670-81. | Article | PubMed Abstract | PubMed FullText

6. Beitchman JH, Baldassarra L, Mik H, De Luca V, King N, Bender D, Ehtesham $\mathrm{S}$ and Kennedy JL. Serotonin transporter polymorphisms and persistent, pervasive childhood aggression. Am J Psychiatry. 2006; 163:1103-5. | Article | PubMed

7. Belsky J, Jonassaint $C$, Pluess $M$, Stanton $M$, Brummett B and Williams R. Vulnerability genes or plasticity genes? Mol Psychiatry. 2009; 14:746-54. | Article | PubMed Abstract | PubMed FullText

8. Blakely RD, De Felice $L J$ and Hartzell HC. Molecular physiology of norepinephrine and serotonin transporters. J Exp Biol. 1994; 196:263-81. Article | PubMed

9. Borg J, Henningsson S, Saijo T, Inoue M, Bah J, Westberg L, Lundberg J, Jovanovic H, Andree B, Nordstrom AL, Halldin C, Eriksson E and Farde L. Serotonin transporter genotype is associated with cognitive performance but not regional 5-HT1A receptor binding in humans. Int $J$ Neuropsychopharmacol. 2009; 12:783-92. | Article | PubMed

10. Carlsson I, Wendt PE and Risberg J. On the neurobiology of creativity. Differences in frontal activity between high and low creative subjects. Neuropsychologia. 2000; 38:873-85. | Article | PubMed

11. Deary IJ, Johnson W and Houlihan LM. Genetic foundations of human intelligence. Hum Genet. 2009; 126:215-32. | Article | PubMed

12. De Barros D.P, Primi R, Miguel F.K, Almeida L.S and Oliveira E.P. Metaphor Creation: a measure of creativity or intelligence? European Journal of Education and Psychology. 2010; 3:103-115.

13. Du L, Bakish D and Hrdina PD. Gender differences in association between serotonin transporter gene polymorphism and personality traits. Psychiatr Genet. 2000; 10:159-64. | PubMed

14. Eley TC, Sugden K, Corsico A, Gregory AM, Sham P, McGuffin P, Plomin $R$ and Craig IW. Gene-environment interaction analysis of serotonin system markers with adolescent depression. Mol Psychiatry. 2004; 9:908-15. | Article | PubMed

15. Eysenck H.J. Check your own IQ. Penguin, Harmondsworth, England. 1970.

16. Feinn R, Nellissery M and Kranzler HR. Meta-analysis of the association of a functional serotonin transporter promoter polymorphism with alcohol dependence. Am J Med Genet B Neuropsychiatr Genet. 2005; 133B:79-84. | Article | PubMed

17. Fox E, Zougkou K, Ridgewell A and Garner K. The serotonin transporter gene alters sensitivity to attention bias modification: evidence for a plasticity gene. Biol Psychiatry. 2011; 70:1049-54. | Article | PubMed Abstract I PubMed FullText

18. Gaspar P, Cases $O$ and Maroteaux L. The developmental role of serotonin: news from mouse molecular genetics. Nat Rev Neurosci. 2003; 4:1002-12. | Article | PubMed

19. Gerra G, Garofano L, Santoro G, Bosari S, Pellegrini C, Zaimovic A, Moi G, Bussandri M, Moi A, Brambilla F and Donnini C. Association between low-activity serotonin transporter genotype and heroin dependence: behavioral and personality correlates. Am J Med Genet B Neuropsychiatr Genet. 2004; 126B:37-42. | Article | PubMed

20. Glascher J, Rudrauf D, Colom R, Paul LK, Tranel D, Damasio H and Adolphs $R$. Distributed neural system for general intelligence revealed by lesion mapping. Proc Natl Acad Sci U S A. 2010; 107:4705-9. | Article | PubMed Abstract | PubMed FullText

21. Gorwood P, Batel P, Ades J, Hamon M and Boni C. Serotonin transporter gene polymorphisms, alcoholism, and suicidal behavior. Biol Psychiatry.

\section{0; 48:259-64. | Article | PubMed}

22. Haensly P.A and Reynolds C.R. Creativity and intelligence. In J. A. Glover, R. R. Ronning, Reynolds C. R. (Eds.), Handbook of creativity. New York: Plenum. 1989; 111-132.

23. Hariri AR and Holmes A. Genetics of emotional regulation: the role of the serotonin transporter in neural function. Trends Cogn Sci. 2006; 10:182-91. | Article | PubMed

24. Herman Al, Philbeck JW, Vasilopoulos NL and Depetrillo PB. Serotonin transporter promoter polymorphism and differences in alcohol consumption behaviour in a college student population. Alcohol Alcohol. 2003; 38:446-9. | PubMed

25. Homberg JR and Lesch KP. Looking on the bright side of serotonin transporter gene variation. Biol Psychiatry. 2011; 69:513-9. | Article | PubMed

26. Hu XZ, Lipsky RH, Zhu G, Akhtar LA, Taubman J, Greenberg BD, Xu K, Arnold PD, Richter MA, Kennedy JL, Murphy DL and Goldman D. Serotonin transporter promoter gain-of-function genotypes are linked to obsessive-compulsive disorder. Am J Hum Genet. 2006; 78:815-826. | Article | PubMed Abstract | PubMed FullText

27. Hu X, Oroszi G, Chun J, Smith TL, Goldman D and Schuckit MA. An expanded evaluation of the relationship of four alleles to the level of response to alcohol and the alcoholism risk. Alcohol Clin Exp Res. 2005; 29:8-16. | Article | PubMed

28. Jacobs BL and Azmitia EC. Structure and function of the brain serotonin system. Physiol Rev. 1992; 72:165-229. I Article I PubMed

29. Jauk E, Benedek M and Neubauer AC. Tackling creativity at its roots: evidence for different patterns of EEG alpha activity related to convergent and divergent modes of task processing. Int J Psychophysiol. 2012; 84:219-25. | Article | PubMed Abstract | PubMed FullText

30. Jaykaran, Bhardwaj P, Kantharia ND, Yadav P and Panwar A. Effect of fluoxetine on some cognitive functions of patients of depression. Indian J Psychol Med. 2009; 31:24-9. | Article | PubMed Abstract | PubMed FullText

31. Jensen A.R. Bias in mental testing. Free Press, New York. 1980.

32. Jonassen R, Endestad T, Neumeister A, Foss Haug KB, Berg JP and Landro $\mathrm{NI}$. The effects of the serotonin transporter polymorphism and age on frontal white matter integrity in healthy adult women. Front Hum Neurosci. 2012; 6:19. | Article | PubMed Abstract | PubMed FullText

33. Kim K.H. Can only intelligent people be creative? A meta-analysis. Journal of Secondary Gifted Education. 2005; 16:57-66.

34. Kosek E, Jensen KB, Lonsdorf TB, Schalling M and Ingvar M. Genetic variation in the serotonin transporter gene (5-HTTLPR, rs25531) influences the analgesic response to the short acting opioid Remifentanil in humans. Mol Pain. 2009; 5:37. | Article | PubMed Abstract | PubMed FullText

35. Lesch KP, Bengel D, Heils A, Sabol SZ, Greenberg BD, Petri S, Benjamin J, Muller CR, Hamer DH and Murphy DL. Association of anxiety-related traits with a polymorphism in the serotonin transporter gene regulatory region. Science. 1996; 274:1527-31. | Article | PubMed

36. Lesch KP and Gutknecht L. Pharmacogenetics of the serotonin transporter. Prog Neuropsychopharmacol Biol Psychiatry. 2005; 29:1062-73. | Article | PubMed

37. Liao DL, Hong CJ, Shih HL and Tsai SJ. Possible association between serotonin transporter promoter region polymorphism and extremely violent crime in Chinese males. Neuropsychobiology. 2004; 50:284-7. | Article | PubMed

38. Maluchenko NV, Schegolkova JV, Kulikova MA, Timofeeva MA, Shlepcova VA, Sysoeva OV and Tonevitsky AG. Gender effects on association of serotonin transporter gene polymorphism with symptoms of central fatigue. Bull Exp Biol Med. 2009; 147:462-5. I PubMed

39. Manuck SB, Flory JD, Ferrell RE and Muldoon MF. Socio-economic status covaries with central nervous system serotonergic responsivity as a function of allelic variation in the serotonin transporter gene-linked polymorphic region. Psychoneuroendocrinology. 2004; 29:651-68. | Article | PubMed

40. Meneses $A$ and Hong E. Effect of fluoxetine on learning and memory 
involves multiple 5-HT systems. Pharmacol Biochem Behav. 1995; 52:341-6. | Article | PubMed

41. Noguera NI, Tallano CE, Bragos IM and Milani AC. Modified salting-out method for DNA isolation from newborn cord blood nucleated cells. J Clin Lab Anal. 2000; 14:280-3. | PubMed

42. Mizuno T, Aoki M, Shimada $Y$, Inoue $M$, Nakaya $K$, Takahashi T, Itoyama Y, Kanazawa M, Utsumi A, Endo Y, Nomura T, Hiratsuka M, Mizugaki M, Goto J, Hongo $M$ and Fukudo $S$. Gender difference in association between polymorphism of serotonin transporter gene regulatory region and anxiety. J Psychosom Res. 2006; 60:91-7. | Article | PubMed

43. Nikiforuk $A$ and Popik P. Long-lasting cognitive deficit induced by stress is alleviated by acute administration of antidepressants. Psychoneuroendocrinology. 2011; 36:28-39. | Article | PubMed

44. Nusbaum E.C and Silvia P.J. Are intelligence and creativity really so different? Fluid intelligence, executive processes, and strategy use in divergent thinking. Intelligence. 2011; 39:36-45.

45. Rietveld CA, Medland SE, Derringer J, Yang J, Esko T, Martin NW, Westra HJ, Shakhbazov K, Abdellaoui A, Agrawal A, Albrecht E, Alizadeh BZ, Amin N, Barnard J, Baumeister SE, Benke KS and Bielak LF et al. GWAS of 126,559 individuals identifies genetic variants associated with educational attainment. Science. 2013; 340:1467-71. | Article | PubMed Abstract | PubMed FullText

46. Roiser JP, Muller U, Clark L and Sahakian BJ. The effects of acute tryptophan depletion and serotonin transporter polymorphism on emotional processing in memory and attention. Int I Neuropsychopharmacol. 2007; 10:449-61. | Article | PubMed Abstract | PubMed FullText

47. Roiser JP, Rogers RD, Cook LJ and Sahakian BJ. The effect of polymorphism at the serotonin transporter gene on decision-making, memory and executive function in ecstasy users and controls. Psychopharmacology (Berl). 2006; 188:213-27. | Article | PubMed Abstract | PubMed FullText

48. Salminen LE, Schofield PR, Pierce KD, Lane EM, Heaps JM, Bolzenius JD, Baker LM, Luo $X$ and Paul RH. Triallelic relationships between the serotonin transporter polymorphism and cognition among healthy older adults. Int J Neurosci. 2014; 124:331-8. | Article | PubMed

49. Sharpley C.F. The role of genes (and environmental stress) in depression: an update. Current Psychiatry Reviews. 2011; 7:84-95.

50. Sternberg R.J and O'Hara L.A. Intelligence and creativity. In R. J. Sternberg (Ed.), Handbook of intelligence, New York: Cambridge University Press. 2000; 611-630.

51. Stoltenberg SF and Vandever JM. Gender moderates the association between 5-HTTLPR and decision-making under ambiguity but not under risk. Neuropharmacology. 2010; 58:423-8. | Article | PubMed Abstract | PubMed FullText

52. Uher R and McGuffin P. The moderation by the serotonin transporter gene of environmental adversity in the etiology of depression: 2009 update. Mol Psychiatry. 2010; 15:18-22. | Article | PubMed

53. Volf NV, Kulikov AV, Bortsov CU and Popova NK. Association of verbal and figural creative achievement with polymorphism in the human serotonin transporter gene. Neurosci Lett. 2009; 463:154-7. | Article | PubMed

54. Wendland JR, Martin BJ, Kruse MR, Lesch KP and Murphy DL. Simultaneous genotyping of four functional loci of human SLC6A4, with a reappraisal of 5-HTTLPR and rs25531. Mol Psychiatry. 2006; 11:224-6. | Article | PubMed

55. Wilhelm K, Mitchell PB, Niven H, Finch A, Wedgwood L, Scimone A, Blair $I$, Parker $G$ and Schofield PR. Life events, first depression onset and the serotonin transporter gene. Br J Psychiatry. 2006; 188:210-5. | Article | PubMed

\section{Citation:}

Volf N.V, Sinyakova N.A, Osipova L.P, Kulikov A.V and Belousova L.V. Association between intelligence quotient and the 5HTTLPR polymorphism of human serotonin transporter coding gene. J Psychiatry Brain Funct. 2015; 2:8.

http://dx.doi.org/10.7243/2055-3447-2-8 